\title{
The Starter Effect of Non-Symbiotic Microbial Bioproducts on Wheat
}

\author{
Roxana VIDICAN, Vlad STOIAN*, Ioan ROTAR, Florin PĂCURAR \\ Faculty of Agriculture. Department of Plant Culture, University of Agricultural Sciences and Veterinary \\ Medicine Cluj-Napoca, 3-5 Manăștur street 400372, Cluj-Napoca, Romania \\ * corresponding author: vlad.stoian@usamvcluj.ro
}

Bulletin USAMV series Agriculture 74(2)/2017

Print ISSN 1843-5246; Electronic ISSN 1843-5386

DOI 10.15835/buasvmcn-agr: 0031

\begin{abstract}
Microbial groups developed in the rhizosphere ensure the stability and dynamics of nutrient transfer processes to plants. Additional soil inoculation with rhizospheric bacteria acts to expand the ecological niche, supplements the activity, the number of individuals and promote plant growth. In today's agriculture, there is a need for the usage of rhizosphere microflora and integrative approaches to stimulate plant growth. The aim of the study is to evaluate the use of biofertilizers as starter stimulators in autumn wheat. Different concentrations of Bactofil, containing rhizospheric bacteria, were applied in small rhizothrones. Evaluation of relationships between bacterial inoculum and plant reveals the degree of applicability and adaptation to the soil conditions of exogenous microflora. Doses of $15.6 \times 10^{8}$ and $20.8 \times 10^{8}$ cells $/ \mathrm{m}^{2}$ stimulates the root elongation and higher level of mycorrhization. Bioproducts can be viable solutions to stimulate the initial development of wheat plants.
\end{abstract}

Keywords: bacterial bioproducts, winter wheat, mycorrhiza

\section{INTRODUCTION}

Rhizosphere represents the narrow area around the plant roots and is a very dynamic environment. The area is dominated by a diverse microbial community and is strongly influenced by root exudates, represented by sugars, amino acids, fatty acids, enzymes, growth regulators and secondary metabolites (Carvalhais et al., 2011, Jones et al., 2004). Release of root exudates together with decomposed vegetal material provides carbon sources for heterotrophic soil biota (Aroca, 2013). Microorganisms in the rhizosphere play the role of intermediary between plants and soil, establishing complex interrelationships throughout the vegetation period and can perform functions such as soil improvement, degradation of pollutants and removal of dangerous compounds from ecosystem (Arora, 2015, Sandor et al., 2016). Rhizosphere control is a key process in mechanisms needed to solve critical issues facing the planet, including agriculture, improvement of water quality, climate change mitigation and biodiversity conservation (Trabelsi and Mhamdi, 2013).

The plants co-evolved into contact with a large number of microorganisms over millions of years, the rhizosphere becoming a specialized environment that ensures increased availability of nutrients and productivity (Slaughter, 2016, Varma and Kharkwal, 2009). The symbiotic association between plants and fungi occurred over 400 million years ago (Bonfante, 2009), the interaction being as old as the appearance of plants on the earth (Gutjahr and Parniske, 2013) and partners have been selected following a long evolutionary process. Arbuscular mycorrhizas are symbiotic associations defined by arbuscules and vesicles as intracellular structures, formed within the root during the stages of development (Bonfante and Genre, 2010). This type of mycorrhiza does not cause changes in the root structure, the fungi having both intradicular and 
intracellular development. Mycorrhizal symbiosis is considered to be a highly adaptive mechanism of plants from various systematic units (Brundrett, 2002), and their absence is an exception.

In the current context of agriculture, soil fertility is seen from the perspective of atmospheric nitrogen fixation potential, phosphorus solubility, structure maintenance, xenobiotic breakdown and plant pathogen control. In the absence of these functions, the soil is considered a non-living entity with minerals and chemical compounds. Functional microbial soil groups are considered to be those involved in the nutrient and organic matter circuit, acting directly in one or more biochemical circuits (Onica et al., 2017, Rai, 2005). Bacteria are the most numerous microorganisms in the soil, being able to obtain energy and nutrients by decomposing plant matter and root exudates, establishing the level of competition of host plants (Paracer and Ahmajian, 2000). Plant growth is limited by the amount of nitrogen in the soil, naturally the supply of nitrogen compounds beeing ensured by bacteria (Santi et al., 2013, Cocking, 2003, Kneip et al., 2007).

Microbial bioproducts are solutions that contain living organisms capable of colonizing the rhizosphere and transferring essential nutrients to plants, in order to improve their growth and development. Formulas of complex consortia applied to seeds, roots or soil are used to increase the availability of nutrients through their biological activity, also helping to efficiently reconvert existing microflora (Bhattacharjee and Dey, 2014). The necessity of using microbial bioproducts resulted from two reasons: increasing agricultural production and reducing the use of mineral fertilizers (Bahadur et al., 2015).

\section{MATERIALS AND METHODS}

This study aims to evaluate the potential of biofertilizers as starters and stabilizers of root development of winter wheat. The experiment was installed under controlled conditions in rhizothrones, with a biological material represented by Arieşan variety, created at ARDS Turda. On soil were applied different concentrations of Bactofil B10, a biofertilizer based on Azospirillium lipoferium, Azotobacter vinelandii, Bacillus megaterium, B. circulans, B. subtilis, Pseudomonas fluorescens, Micrococcus roseus, macro and micro elements, biosynthesized enzymes, growth stimulators, plant hormones and vitamins produced by Agrobio (www.agrobio.ro). Along with the uninoculated variant, considered as control (co), the concentrations applied were of $5.2 \times 10^{8}$ cells $/ \mathrm{m}^{2}$ (da), $10.4 \times 10^{8}$ cells $/ \mathrm{m}^{2}(\mathrm{db})$, $15.6 \times 10^{8}$ cells $/ \mathrm{m}^{2}$ (dc) și $20.8 \times 10^{8}$ cells $/ \mathrm{m}^{2}$ (dd). The soil used in the experiment was a phaeoziom argic with a $\mathrm{pH}$ of 6.5 , humus $3.44 \%, \mathrm{~N}-\mathrm{NO}_{3} 7.65$ ppm, N-NH 1.74 ppm, Nmin 17.72 ppm, P-Al 25 ppm.

Assessment of the relationship between the bacterial inoculum and plants is carried out under controlled growth conditions in order to assess the degree of applicability and adaptation to the soil conditions of products with exogenous microflora. Above- and bellowground development of plants was analyzed at 3 weeks after their emergence. For an overview of the effect of the applied inoculum, the ratios of the root and shoot biomass were calculated, also the percentage of participation of each component in the total biomass of the plant. The level and dependence of plants toward mycorrhizas was assessed using the method described by Stoian et al. (2016). Identification of effective inoculation concentrations provides a much clearer picture of mycorrhizal mechanism in winter wheat based on synergistic microbial supplementation in the rhizosphere. Data analysis was performed with RStudio (R Core Team, 2017), packages "agricolae" (de Mendiburu, 2017) for ANOVA and Fisher-LSD and "vegan" (Oksanen et al., 2017) for PCA plots.

\section{RESULTS AND DISCUSSIONS}

Based on the results of ANOVA, a reduced impact of applied treatments on vegetative development can be observed compared to mycorrhizal symbiotic status (Tab. 1). The root is more strongly influenced than aboveground growth, with similar standard deviations, but without statistical assurance. In contrast, the root/shoot ratio and root percentage throughout the plant show significant variations due to the application of different doses. For mycorrhizas, the strongest influence of treatment is visible at the frequency of phenomenon, the mean being set at a value close to $90 \%$. The standard deviation of the intensity and degree of colonization is over $7 \%$, indicating the effectiveness of soil inoculation with bacteria as a support in promoting the natural mechanisms of mycorrhization. Arbuscules 
Tab. 1. Variation of vegetative and mycorrhizal parameters due to the application of treatments

\begin{tabular}{|c|c|c|c|c|c|c|c|}
\hline Vegetative & Mean \pm S.D. & $F$ & $p$ & Mycorrhizal & Mean \pm S.D. & $F$ & $p$ \\
\hline root length $(\mathrm{cm})$ & $7.12 \pm 2.01$ & 1.36 & 0.32 & $\begin{array}{c}\text { frequency } \\
(\%)\end{array}$ & $88.44 \pm 9.58$ & 45.72 & $\mathrm{p}<0.001$ \\
\hline shoot length $(\mathrm{cm})$ & $42.76 \pm 2.18$ & 0.47 & 0.76 & intensity (\%) & $18.74 \pm 7.13$ & 31.80 & $\mathrm{p}<0.001$ \\
\hline root/shoot (g) & $0.56 \pm 0.60$ & 3.75 & 0.04 & arbuscules & $0.34 \pm 0.49$ & 7.52 & $\mathrm{p}<0.001$ \\
\hline root percent (\%) & $30.57 \pm 15.94$ & 4.88 & 0.02 & $\begin{array}{c}\text { colonization } \\
\text { degree }(\%)\end{array}$ & $17.15 \pm 7.51$ & 32.65 & $\mathrm{p}<0.001$ \\
\hline
\end{tabular}

Note: Significant variations (ANOVA test $-\mathrm{F}, \mathrm{p}<0.05 / \mathrm{p}<0.01 / \mathrm{p}<0.001$ ).

Tab. 2. Dynamics of interaction microbial consortium - plant development (Mean \pm S.D.)

\begin{tabular}{ccccc}
\hline Treatment & root length $(\mathrm{cm})$ & shoot length $(\mathrm{cm})$ & root/shoot $(\mathrm{g})$ & root percent $(\%)$ \\
\hline $\mathrm{co}$ & $6.50 \pm 1.32 \mathrm{a}$ & $42.00 \pm 2.03 \mathrm{a}$ & $0.41 \pm 0.11 \mathrm{~b}$ & $28.94 \pm 5.91 \mathrm{ab}$ \\
\hline $\mathrm{da}$ & $6.17 \pm 1.04 \mathrm{a}$ & $44.36 \pm 1.41 \mathrm{a}$ & $1.46 \pm 0.96 \mathrm{a}$ & $54.53 \pm 18.63 \mathrm{a}$ \\
\hline $\mathrm{db}$ & $5.92 \pm 1.42 \mathrm{a}$ & $42.67 \pm 2.81 \mathrm{a}$ & $0.33 \pm 0.23 \mathrm{~b}$ & $23.65 \pm 12.03 \mathrm{ab}$ \\
\hline $\mathrm{dc}$ & $8.33 \pm 2.25 \mathrm{a}$ & $42.50 \pm 3.12 \mathrm{a}$ & $0.23 \pm 0.11 \mathrm{~b}$ & $18.34 \pm 6.98 \mathrm{~b}$ \\
\hline $\mathrm{dd}$ & $8.67 \pm 2.89 \mathrm{a}$ & $42.25 \pm 2.05 \mathrm{a}$ & $0.38 \pm 0.09 \mathrm{~b}$ & $27.40 \pm 5.19 \mathrm{ab}$ \\
\hline
\end{tabular}

Note: Different letters between treatments denote significant differences (LSD test, $\mathrm{p}<0.01$ ).

have low mean values, due in particular to the ephemerity of these structures compared to the cells they colonize (Kobae and Hata, 2010, Parniske, 2008).

The root length varies within $2-3 \mathrm{~cm}$ due to the application of the treatments (Tab. 2), but without significant differences. High doses of inoculum ( $\mathrm{dc}$ and $\mathrm{dd}$ ) lead to a root growth over $8 \mathrm{~cm}$, as an opposite aboveground increases being higher at low dose rates. The phenomenon indicates the stronger effect of bacteria on root growth in this growth phase Souza et al., 2015, Vachero et al., 2013), providing a greater support for the further development of mycorrhizal fungi. The root/shoot ratio is higher at low doses, with a statistically maximum at a dose of $5.2 \times 10^{8}$ cells / $\mathrm{m}^{2}$ (da). Following this trend, the same treatment had a root percentage in the entire plant over $54 \%$. In this context, the bacteria have acted to produce a small root, but well provisioned with nutrients and smaller amount of transferred untrients in shoot. An interesting aspect is visible at the dose $15.6 \times 10^{8}$ cells $/ \mathrm{m}^{2}(\mathrm{dc})$, which leads to the formation of a long root $(8.33 \mathrm{~cm})$ but occupies less than $20 \%$ of the total weight of the plant. This phenomenon is due to the potential of inoculated bacteria to promote plant growth and by providing the necessary nitrogen and phosphorus in the first growth phases (Bashan and de-Bashan, 2005, Majeed et al., 2015).

Datas on vegetative development are partly supported by mycorrhizal development in root system (Tab. 3). The only variant with a $100 \%$ frequency is with $15.6 \times 10^{8}$ cells $/ \mathrm{m}^{2}$ (dc), with significant differences o control (co) and dose of $5.2 \times 10^{8}$ cells $/ \mathrm{m}^{2}$ (da). This parameter is completed by an intensity of over $25 \%$, indicating a rapid transfer of nutrients to the shoots and the plant's investment in their quantitative fixation (Saia et al., 2015, Ahemat and Kibret, 2014). The intensity is increased in conditions of increasing the number of inoculated cells in soil, indicating a synergistic effect of bacteria with mycorrhizal fungi. Under non-inoculation conditions, the frequency and intensity remain within the limits of a lax association of mycorrhizas with wheat roots (Stoian et al., 2016), the transfer of nutrients working poorly between the symbions. 
Arbuscularity is reduced in roots, the maximum being reached at the application of a high dose of inoculum, $15.6 \times 10^{8}$ cells $/ \mathrm{m}^{2}(\mathrm{dc})$. The ephemerity of structures and reduced presence in root cells indicate an increased transfer potential between partners over short periods of time. The volume occupied by mycorrhizas in roots, as colonization degree, is higher at the maximum inoculum doses, with over $20 \%$ of the volume, indicating a high potential for synergism with inoculated bacteria (Saxena and Minaxi, 2014).

The main components show an explanation of the parameters variation of $97.53 \%$ on the first 3 axis of the ordering, with a high weight on the first axis (Tab. 4.). Factors are loaded on the first two axes, except for the length of the root that is located on the axis 3. The PCA graph shows the separation of vegetation parameters from those of the micoride in different planes in response to applied treatments (Fig. 1.). Shoot development is sensitive to absence and inoculum dose (Bashan, 1986, Bharti et al., 2016, Lindberg et al., 1985). At low dose inoculum (da) the root percentage and root/shoot ratio have the highest values, with insertion in PCA Axis 1. Arbuscules, colonization degree, and mycorrhizal intensity are loaded onto PCA axis 1 and positioned in the high inoculum (dc) area.

\section{CONCLUSIONS}

Application of bacterial inoculum in the winter wheat rhizosphere leads to a significant increase in the vegetative parameters reports. At doses of $5.2 \times 10^{8}$ cells $/ \mathrm{m}^{2}$, roots have the highest weight

Tab. 3. Dynamics of the interaction microbial consortium - mycorrhizal mechanism (Mean \pm S.D.)

\begin{tabular}{ccccc}
\hline Treat & frequency (\%) & intensity (\%) & arbuscules (\%) & colonization degree (\%) \\
\hline co & $73.33 \pm 3.33 \mathrm{~d}$ & $6.90 \pm 1.00 \mathrm{c}$ & $0.01 \pm 0.01 \mathrm{~b}$ & $5.08 \pm 0.96 \mathrm{c}$ \\
\hline $\mathrm{da}$ & $85.56 \pm 3.85 \mathrm{c}$ & $17.50 \pm 3.64 \mathrm{~b}$ & $0.04 \pm 0.05 \mathrm{~b}$ & $15.07 \pm 3.87 \mathrm{~b}$ \\
\hline $\mathrm{db}$ & $94.44 \pm 1.92 \mathrm{ab}$ & $19.52 \pm 2.19 \mathrm{a}$ & $0.35 \pm 0.07 \mathrm{ab}$ & $18.45 \pm 2.25 \mathrm{~b}$ \\
\hline $\mathrm{dc}$ & $100.00 \pm 0.00 \mathrm{a}$ & $25.89 \pm 1.68 \mathrm{ab}$ & $1.13 \pm 0.64 \mathrm{a}$ & $25.89 \pm 1.68 \mathrm{a}$ \\
\hline $\mathrm{dd}$ & $88.89 \pm 1.92 \mathrm{bc}$ & $23.88 \pm 2.01 \mathrm{ab}$ & $0.16 \pm 0.06 \mathrm{~b}$ & $21.24 \pm 2.08 \mathrm{ab}$ \\
\hline
\end{tabular}

Note: Different letters between treatments denote significant differences (LSD test, $\mathrm{p}<0.01$ ).

Tab. 4. Factor loadings of parameters and variance explained by PCA (Mean \pm S.D.)

\begin{tabular}{lccc}
\hline & \multicolumn{2}{c}{ PCA Axis } \\
\hline Variance explained & PC 1 & PC 2 & PC 3 \\
\cline { 2 - 4 } & 69.12 & 25.13 & 0.03 \\
\hline & & Factor loading & \\
\cline { 2 - 4 } & PC 1 & PC 2 & PC 3 \\
\hline root length & 0.006 & 0.026 & -0.122 \\
\hline shoot length & -0.067 & 0.156 & 0.019 \\
\hline root/shoot & -0.082 & -0.058 & 0.004 \\
\hline root percent & -0.412 & -0.188 & 0.003 \\
\hline frequency & 0.073 & 0.121 & 0.023 \\
\hline intensity & 0.241 & -0.140 & 0.004 \\
\hline arbuscularity & 0.110 & -0.016 & -0.012 \\
\hline colonization degree & 0.287 & -0.157 & 0.008 \\
\hline
\end{tabular}




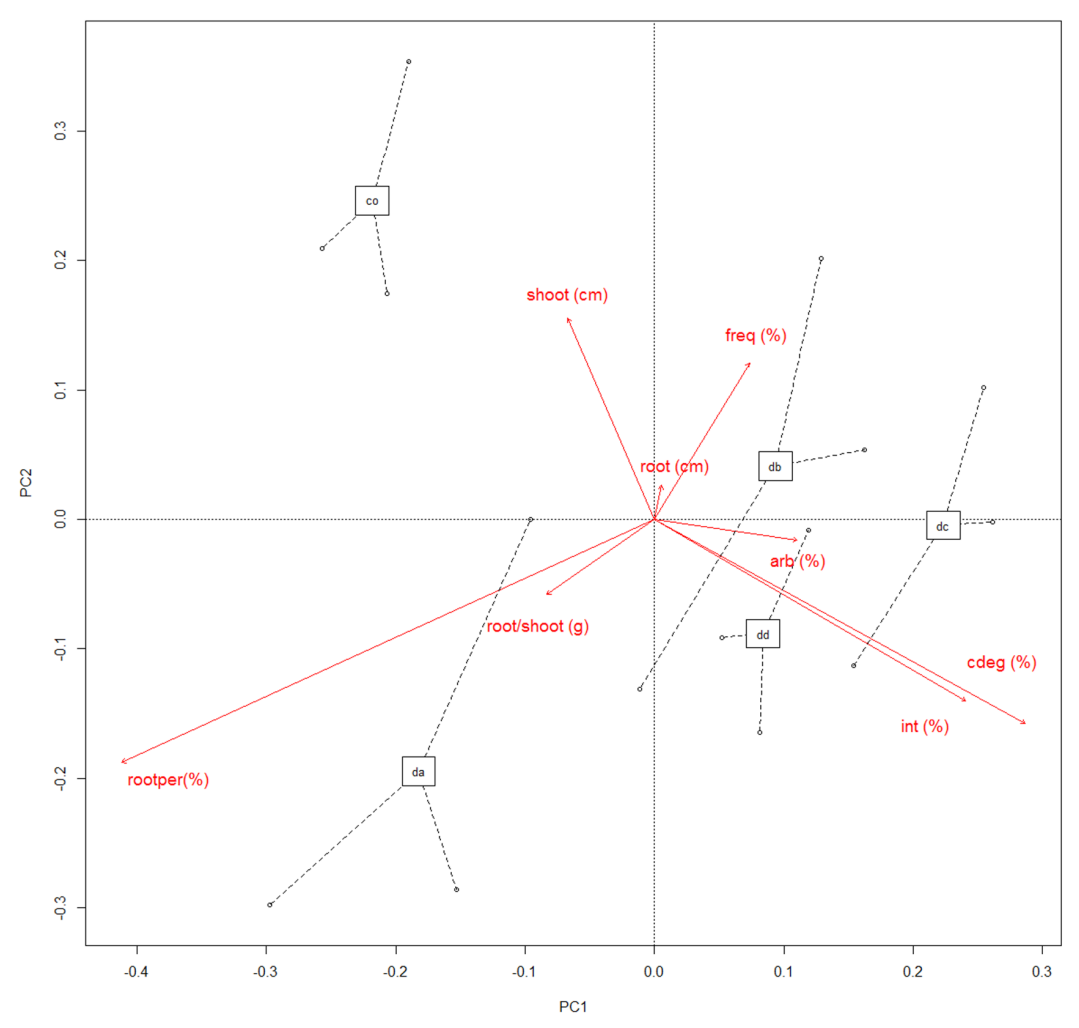

Fig. 1. PCA analysis of vegetation vs. mycorrhizal parameters

Legend: Vegetative parameters: shoot - shoot length; root - root length; rootper - root percent from entire plant. Mycorrhizal parameters: freq - frequency; int - intensity; arb - arbuscularity; cdeg - colonization degree.

and decrease as the inoculum dose increases. At doses of $15.6 \times 10^{8}$ cells $/ \mathrm{m}^{2}$ and $20.8 \times 10^{8}$ cells/ $\mathrm{m}^{2}$, the roots have a length of over $8 \mathrm{~cm}$ and a high level of mycorrhization. Maximum arbuscular transfer is visible at a dose of $15.6 \times 10^{8}$ cells $/ \mathrm{m}^{2}$.

\section{REFERENCES}

1. Ahemad M, Kibret M, (2014). Mechanisms and applications of plant growth promoting rhizobacteria: current perspective. Journal of King Saud UniversityScience, 26(1):1-20.

2. Aroca R Ed. (2013). Symbiotic endophytes. Springer.

3. Arora NK Ed. (2015). Plant microbes symbiosis: Applied facets (147). Springer.

4. Bahadur B, Venkat Rajam M, Sahijram L, Krishnamurthy KV Eds. (2015). Plant Biology and Biotechnology, Vol. II: Plant Geonomics and Biotechnology, Springer, New Delphi.

5. Bashan Y (1986). Significance of timing and level of inoculation with rhizosphere bacteria on wheat plants. Soil Biology and Biochemistry, 18(3):297-301.

6. Bashan Y, de-Bashan LE (2005). Fresh-weight measurements of roots provide inaccurate estimates of the effects of plant growth-promoting bacteria on root growth: a critical examination. Soil Biology \& Biochemistry, 37:1795-1804.
7. Bharti N, Pandey SS, Barnawal D, Patel VK, Kalra A (2016). Plant growth promoting rhizobacteria Dietzia natronolimnaea modulates the expression of stress responsive genes providing protection of wheat from salinity stress. Scientific reports, 6 .

8. Bhattacharjee R, Dey U (2014). Biofertilizer, a way towards organic agriculture: A review. African Journal of Microbiology Research, 8(24):2332-2343.

9. Bonfante P, Genre A (2010). Mechanisms underlying beneficial plant-fungus interactions in mycorrhizal symbiosis. Nature communications, 1(4):48.

10. Brundrett MC (2002). Coevolution of roots and mycorrhizas of land plants. New phytologist, 154(2):275304.

11. Carvalhais LC, Dennis PG, Fedoseyenko D, Hajirezaei MR, Borriss R, von Wirén N (2011). Root exudation of sugars, amino acids, and organic acids by maize as affected by nitrogen, phosphorus, potassium, and iron deficiency. Journal of Plant Nutrition and Soil Science, 174(1):3-11.

12. Cocking EC (2003). Endophytic colonization of plant roots by nitrogen-fixing bacteria. Plant and soil, 252(1):169175.

13. de Mendiburu F (2017). agricolae: Statistical Procedures for Agricultural Research. R package version 1.2-6. https://CRAN.R-project.org/package=agricolae. 
14. Gutjahr C, Parniske M (2013). Cell and developmental biology of arbuscular mycorrhiza symbiosis. Annual Review of Cell and Developmental Biology, 29.

15. Jones DL, Hodge A, Kuzyakov Y (2004). Plant and mycorrhizal regulation of rhizodeposition. New Phytologist, 163(3):459-480.

16. Kneip C., Lockhart P, Voß C, Maier UG (2007). Nitrogen fixation in eukaryotes-new models for symbiosis. BMC Evolutionary Biology, 7(1):55.

17. Kobae Y, Hata S (2010). Dynamics of periarbuscular membranes visualized with a fluorescent phosphate transporter in arbuscular mycorrhizal roots of rice. Plant and Cell Physiology, 51(3):341-353.

18. Lindberg T, Granhall U, Tomenius K (1985). Infectivity and acetylene reduction of diazotrophic rhizosphere bacteria in wheat (Triticum aestivum) seedlings under gnotobiotic conditions. Biology and fertility of soils, 1(3):123-129.

19. Majeed A, Abbasi MK, Hameed S, Imran A, Rahim N (2015). Isolation and characterization of plant growth-promoting rhizobacteria from wheat rhizosphere and their effect on plant growth promotion. Frontiers in Microbiology; 6:198. doi:10.3389/fmicb.2015.00198.

20. Oksanen J, Guillaume Blanchet F, Friendly M, Kindt R, Legendre P, McGlinn D, Minchin PR, O'Hara RB, Simpson GL, Solymos P, Stevens MHH, Szoecs E, Wagner H (2017). vegan: Community Ecology Package. $\mathrm{R}$ package version 2.4-3. https://CRAN.R-project.org/package=vegan

21. Onica BM, Sandor V, Brad T, Vidican R, Sandor M (2017). Changes of soil functional diversity induced by the use of different fertilizers. In EGU General Assembly Conference Abstracts, 19:9944.

22. Paracer S, Ahmadjian V (2000). Symbiosis: an introduction to biological associations. Oxford University Press.

23. Parniske M (2008). Arbuscular mycorrhiza: the mother of plant root endosymbioses. Nature Reviews Microbiology, 6(10):763-775.

24. R Core Team (2017). R: A language and environment for statistical computing. R Foundation for Statistical Computing, Vienna, Austria. URL https://www.R-project. org/.
25. Rai M Ed. (2006). Handbook of microbial biofertilizers. CRC Press.

26. Saia S, Rappa V, Ruisi P, Abenavoli MR, Sunseri F, Giambalvo D, Martinelli F (2015). Soil inoculation with symbiotic microorganisms promotes plant growth and nutrient transporter genes expression in durum wheat. Frontiers in plant science, 6 .

27. Sandor V, Vidican R, Stoian V, Sandor M (2016). Influences of soil texture, biota and fertilizers on community level physiological profile. Research Journal of Agricultural Science, 48(4):157-163.

28. Santi C, Bogusz D, Franche C (2013). Biological nitrogen fixation in non-legume plants. Annals of botany, 111(5):743-767.

29. Saxena J, Minaxi Jha A (2014) Impact of a phosphate solubilizing bacterium and an arbuscular mycorrhizal fungus (Glomus etunicatum) on growth, yield and $\mathrm{P}$ concentration in wheat plants. Clean Soil Air Water. doi:10.1002/clen.201300492.

30. Slaughter LC (2016). Effects of Epichloë coenophiala-tall fescue symbiosis on plant-microbe-soil interactions in a temperate pasture. University of Kentucky.

31. Souza RD, Ambrosini A, Passaglia LM (2015). Plant growth-promoting bacteria as inoculants in agricultural soils. Genetics and molecular biology, 38(4):401-419.

32. Stoian V, Vidican R, Rotar I, Păcurar F, Morea A (2016). Mycorrhizas in Trifolium Repens-A Short Term High Experiment Approach. Agriculture and Agricultural Science Procedia, 10:39-46.

33. Trabelsi D, Mhamdi R (2013). Microbial inoculants and their impact on soil microbial communities: a review. BioMed research international, 2013.

34. Vacheron J, Desbrosses G, Bouffaud ML, Touraine B, Moënne-Loccoz Y, Muller D Prigent-Combaret C (2013). Plant growth-promoting rhizobacteria and root system functioning. Frontiers in plant science, 4.

35. Varma A, Kharkwal AC (2009). Symbiotic fungi. Berlin: Springer. 